\title{
Wyposażenie i wystrój wnętrz siedzib szlachty sandomierskiej w XVII i pierwszej połowie XVIII wieku
}

\begin{abstract}
Słowa kluczowe: wyposażenie, wystrój, siedziby, szlachta, województwo sandomierskie
Key words: furnishings, interior decoration, manor houses, nobility, Sandomierz voivodship
\end{abstract}

W badaniach nad różnorodnymi aspektami dziejów szlachty sandomierskiej w szeroko rozumianym okresie staropolskim zauważa się wyraźnie, że do bardziej zaniedbanych należą te, dotyczące szeroko rozumianego życia codziennego, w tym odnoszące się do kultury materialnej, a więc ,świata rzeczy” i szlacheckiej konsumpcji ${ }^{1}$. Stwierdzenie to tyczy również — tylko nieco częściej podejmowanych — badań nad siedzibami szlacheckimi. W przeważającej mierze studia te koncentrowały się dotąd na największych rezydencjach, z reguły magnackich ${ }^{2}$. Niewiele natomiast powstało dotychczas opracowań na temat warunków mieszkalnych zamożnej, średniej i drobnej szlachty, a więc architektury, wyposażenia, stanu dworów i dworków szlacheckich położonych na obszarze dawnego województwa sandomierskiego ${ }^{3}$. W szerszym zakresie badania nad siedzibami szlacheckimi przeprowadziła Anna Nierychlewska analizując budownictwo obronne na terenie powiatu radomskiego ${ }^{4}$ oraz piszący te słowa, jako autor kilku artykułów na temat siedzib szlachty sandomierskiej w XVII-XVIII w. ${ }^{5}$

Niewątpliwie jedną z podstawowych przyczyn dzisiejszego skromnego stanu badań jest stopień zachowania źródeł pisanych. W wyniku bowiem szeregu katastrof dziejowych, zwłaszcza drugiej wojny światowej, bezpowrotnie zniszczonych zostało wiele podstawowych materiałów źródłowych do dziejów szlachty sandomierskiej, przede wszystkim zaś bogate pod względem zawartości księgi sądów szlacheckich ${ }^{6}$. To właśnie w tych zespołach znajdowały się źródła niezbędne dla tego rodzaju badań, przede wszystkim o charakterze inwentarzowym.

Inwentarze dóbr ziemskich w większości przypadków są obecnie niezastąpione w badaniach nad architekturą i wyposażeniem dworków szlacheckich. W sytuacji bowiem zniszczenia szla-

${ }^{1}$ Zob. przede wszystkim: Katra S., Suchojad H. 2000, s. 449-457; Pielas J. 2004, s. 307-315; tenże 2015, s. 629-635 (tu literatura) i ostatnio tenże 2017a, s. 177-194. O ,świecie rzeczy” szlachty sandomierskiej w pewnym zakresie por. również Szyposz J. 1981, s. 349-364; tejże 1986, s. 451-461.

${ }^{2}$ Dla okresu średniowiecza zob.: Kołodziejski S. 2000, s. 9-18; Kajzer L. 2005 (w pracach tych literatura przedmiotu); Hadamik Cz. 2005. Dla okresu nowożytnego, zob. m.in.: Marciniak-Kajzer A. 2000, s. 19-36; Badowska I. 1968, s. 79-107; Kajzer L. 2000b, s. 37-49; Bania Z. 2000, s. 89-102; Lewicki J. 2000, s. 117-144; Mossakowski S. 2002, s. 23-55.

3 Zob. przede wszystkim: Kajzer L. 2000a, s. 51-66 (tu przegląd badań); Brykowska M. 2000, s. 67-88; Nierychlewska A. 2002 (tu literatura przedmiotu); Chudzińska B., Chudziński K. 1998, s. 5-13; Pielas J. 2007, s. 280-281; Lubczyński M. 2017, s. 269-283.

${ }^{4}$ Nierychlewska A. 2002.

${ }^{5}$ Pielas J. 2001, s. 161-168; tenże 2010, s. 33-52; tenże 2017b, s. 257-267; tenże 2018, s. 126-134.

${ }^{6}$ Zob. ostatnio Źródła. 2009, s. XV-XVII. 
checkich siedzib z XVII-XVIII stulecia, w przeważającej mierze drewnianych, po których nie pozostały żadne ślady w terenie (a także niezachowania siedzib murowanych), opisy zawarte w inwentarzach dóbr ziemskich stanowią jedyną informację o ich funkcjonowaniu?

W wyniku kwerendy przeprowadzonej w różnych zbiorach archiwalnych i bibliotecznych odnalazłem, jak dotąd, ponad 150 inwentarzy dóbr ziemskich z terenu dawnego województwa sandomierskiego. Inwentarze te są sukcesywnie podawane do druku w ramach serii źródłowej „Źródła i materiały do dziejów szlachty województwa sandomierskiego w XVI-XVIII wieku”. Tom drugi wydawnictwa zawiera właśnie edycje inwentarzy szlacheckich dóbr ziemskich z obu stuleci. W pierwszej części było to 38 inwentarzy z lat $1622-1763^{9}$, w drugiej zaś, we współpracy z Katarzyną Justyniarską-Chojak, opublikowanych zostało 30 dokumentów z lat 1635-1789 ${ }^{10}$. Materiał do kolejnej części tego tomu będzie wkrótce przedmiotem starań edytorskich; jasno rysuje się również projekt części czwartej, dzięki kolejnym odnajdowanym archiwaliom. Jednym z efektów tych działań będzie wydanie katalogu siedzib magnackich i szlacheckich w województwie sandomierskim, opisanych w inwentarzach dóbr ziemskich z XVII i XVIII w. ${ }^{11}$

W odnalezionych dotąd i przeanalizowanych na potrzeby niniejszego artykułu inwentarzach znajdują się informacje o blisko 100 siedzibach szlacheckich ${ }^{12}$, w postaci dłuższych lub krótszych ich opisów (w tym kilka opisów tej samej siedziby). Uwzględniono przede wszystkim siedziby należące do drobnej, średniej i w nielicznych przypadkach zamożniejszej szlachty, natomiast rezydencje magnackie (do których odnosi się kilkanaście relacji) przywołano kilkakrotnie dla celów porównawczych. Przekazy te stanowią zasadniczą podstawę źródłową tego opracowania.

W tekście pominięte zostały zagadnienia podstawowe dla oceny funkcjonowania siedzib, takie jak położenie i najbliższe otoczenie, budulec, architektura, układ pomieszczeń itp. Problematyka ta, w znacznej mierze możliwa do opracowania na podstawie inwentarzy dóbr ziemskich, wymagać będzie bowiem odrębnej analizy.

Wykorzystane inwentarze dóbr ziemskich zawierają wiadomości przede wszystkim o następujących elementach wyposażenia i wystroju siedzib szlacheckich: oknach i drzwiach, piecach i kominkach, schodach wewnętrznych, podłogach i sufitach, dekoracjach ścian, oświetleniu izb, meblach oraz niekiedy o innych rzeczach ruchomych znajdujących się we wnętrzach. Stwierdzenie to nie dotyczy inwentarzy, które jedynie informują o istnieniu siedziby szlacheckiej ${ }^{13}$ lub omawiają ją w lakoniczny sposób, jak chociażby we wsi Nieświn (pow. opoczyński, 1745), gdzie inwentaryzator zastał dwór „wszystek zawarty”, więc nie opisał jego wnętrza, ograniczając się do ganku i drzwi prowadzących do wnętrza ${ }^{14}$. Niewielką wartość poznawczą dla rozpa-

7 Zob. m.in.: Chudzińska B., Chudziński K. 1998; Kajzer L. 2004, szczególnie s. 158-183; Rozbicka M. 1999; Augustyniak U. 2001, s. 102-124; Bania Z. 2000; Lubczyński M. 2017.

8 Źródła. 2009; Źródła. 2014.

9 Źródła. 2013.

10 Źródła. 2016.

11 Zob. Pielas J. 2017 b.

12 W tytule i tekście artykułu intencjonalnie użyto terminu ,siedziba szlachecka” w związku z nieprzerwanie powracającą dyskusją badaczy na temat pojęcia „,dworu”, „dworku”. Określenie „,siedziba” dotyczy bowiem dworów i dworków drewnianych, dworów murowanych, fortalicji, pałacyków, pałaców i zamków, zob. m.in.: Jakimowicz T. 1979, s. 15-17; Leśniakowska M. 1996, s. 8; Miłobędzki A. 1980, s. 338; tenże 1976, s. 413-419; tenże 1982, s. 8-16; Chrzanowski T. 1988, s. 281-285; Kajzer L. 1972, s. 451-465; Rozbicka M. 1999, s. $125-137$.

${ }_{13}$ M.in. we wsi Mniszków (pow. opoczyński) w 1650 r., kiedy to w kontekście podziału niw i placów wymieniony jest dwór, Źródła. 2016, s. 7. Por. fragment inwentarza wsi Sieciechowice (pow. pilzneński, 1676): „Dwór i siedlisko dawne dziedziców na Sieciechowicach, ze wszytkiemi budynkami, to jest izbą, komnatą i sionką, jaka jest natenczas [...]", Źródła. 2013, s. 87.

14 Źródła. 2016, s. 165. 
trywanych zagadnień mają również krótkie relacje, takie jak: „Budynek stary przy lamusie, w którym tylko 3 ściany stoją, bez wierzchu, bez wszytkiego, bez pował, stragarzów i płatew i podłogi wcale, nic tylko ściany zgniełe" 15 .

W poddanych analizie opisach siedzib szlacheckich odnaleźć można dużo danych o otworach okiennych, stanowiących istotny element ${ }^{16}$. Jest to zrozumiałe z uwagi choćby na znaczną rozpiętość chronologiczną rozpatrywanych dokumentów oraz użytkowanie siedzib przez przedstawicieli szlachty o różnej zamożności. Różnorodność opisów i wielość informacji na temat otworów okiennych skłania do zajęcia się nimi w odrębnej publikacji ${ }^{17}$, w związku z czym w tym miejscu ograniczę się do podania podstawowych ustaleń.

Liczba okien w danym pomieszczeniu zależna była w znacznym stopniu od jego wielkości. Stąd też w najważniejszych w siedzibach szlacheckich izbach stołowych było ich od trzech do sześciu $^{18}$, a nawet siedem — jak we dworkach w Nieznamierowicach (pow. radomski, 1667) i Radonii (pow. opoczyński, 1667) ${ }^{19}$. W pomieszczeniach mieszkalnych okna przeważnie miały kwatery wypełnione szybami, które w skromniejszych siedzibach oprawione były w drewno ${ }^{20}$, w zamożniejszych zaś w ołów ${ }^{21}$, niekiedy w drewno i ołów jednocześnie ${ }^{22}$. Wśród okien w izbach mieszkalnych wymieniano też okna dwuskrzydłowe ${ }^{23}$ oraz ruchome, tj. posiadające otwierane lub zasuwane szklane kwatery ${ }^{24}$. Tylko w jednym przypadku — dworu magnackiego w mieście Opatowie (1618) — zanotowano okna ukośne (tzw. zams ${ }^{25}$. Niekiedy w inwentarzach notowano również kształt użytych szyb (m.in. okrągłe, kwadratowe, „w cegiełkę”, „okna 3 taflowe”) i rodzaj szkła (,szkło weneckie”) ${ }^{26}$. W oknach w wielu przypadkach zamontowane były metalowe elementy wzmacniające i chroniące mieszkanie przed nieproszonymi gośćmi („,balasy żelazne”, „żelazne szyny nasiekane”, „pręty żelazne”, „ostrwie żelazne”, „sztagi żelazne”, „krata żelazna” itp.) ${ }^{27}$. Niejednokrotnie okna w pomieszczeniach mieszkalnych zaopatrzone były dodatkowo w drewniane okiennice, otwierające się zarówno do wewnątrz, jak i na zewnątrz $^{28}$, albo zasuwane ${ }^{29}$. Otwieranie i zamykanie okien było możliwe dzięki odpowiednim elementom wymienianym w źródłach: zawiasom, skobelkom, kołkom, haczykom ${ }^{30}$. Funkcję ozdobną pełniły pobielane zawiasy oraz listwy otaczające niektóre otwory okienne ${ }^{31}$. We wnę-

15 Tamże, s. 46 (Pęczelice, pow. wiślicki, 1712).

16 Por. m.in. Krótka nauka. 1957, s. 23-25; Augustyniak U. 2001, s. 120-121.

17 Por. ostatnio Bis M. 2014.

18 Źródła. 2013, s. 29, 71, 89, 91, 106, 121; Źródła. 2016, s. 78; Inwentarze. 1999, s. 154.

19 Źródła. 2013, s. 40, 47.

${ }^{20}$ Inwentarz. 2005a, s. 185-186; Źródła. 2013, s. 97; Źródła. 2016, s. 89-90, 132-133.

21 Źródła. 2013, s. 40, 71, 183, 188; Źródła. 2016, s. 25-26, 29-30; Inwentarze. 2003, s. 137-138; Madetko S., Migaszewska B. 2010, s. 53-61.

22 Źródła. 2013, s. 42 (Świeciechów, pow. opoczyński, 1667: „okien troje, półtrzecia w drewno, w pół w ołów”), 121, 149 (Oblęgor Większy, pow. chęciński, 1722: „okna 3 w ołów oprawne, między któremi 3 kwatery w drewno oprawne z okiennicami”; ,okno jedno, połową w ołów, połową w drewno oprawne”), 157; Inwentarz. 1996, s. 181-196.

${ }^{23}$ M.in.: Inwentarz. 2005a, s. 185; Źródła. 2013, s. 183-184.

24 Źródła. 2013, s. 105-107; Źródła. 2016, s. 78-80.

25 Inwentarz. 2005b, s. 158.

${ }^{26}$ M.in.: ANKr., ASangR., sygn. 365, s. 2; Inwentarz. 2005a, s. 185; Inwentarze. 1999, s. 154; Inwentarz. 1996, s. 181-196; Źródła. 2013, s. 155-116, 126; Źródła. 2016, s. 147-148.

${ }^{27}$ M.in.: Źródła. 2013, s. 40-43, 61-62, 71, 95, 97, 188; Inwentarz. 1996, s. 181-196; Inwentarz. 2005a, s. $185-186$.

${ }_{28}$ M.in.: Źródła. 2013, s. 40-43, 71, 149-150, 183-184; Źródła. 2016, s. 25-26.

${ }^{29}$ M.in.: Inwentarz. 1996, s. 181-196; Źródła. 2016, s. 29-30, 78-80.

${ }^{30}$ M.in.: Inwentarze. 1999, s. 153-155; Źródła. 2013, s. 183-184; Źródła. 2016, s. 78-80.

31 M.in.: Źródła. 2013, s. 61-62; Źródła. 2016, s. 78-80. 
trzach użytkowanych jako składy lub o charakterze pomocniczym przeważały okna niewielkie (w komorze „okien dwie maleńkich w drewno”; w komorze „okienko w drewno oprawione nad drzwiami”; w komorze „okienko w niej w ołów oprawne, małe”32), często odpowiednio zabezpieczone (,w sklepie okienko, w którym krata żelazna”; w spiżarce „okno jedno, prętów w nim żelaznych dwa, z zasuwką prostą") ${ }^{33}$, niekiedy zaś na stałe zabite, a więc niespełniające swojej podstawowej roli oświetleniowej, jak m.in. w Baryczy (pow. opoczyński, 1763): w piekarni „okna [...] deszczkami zabite”; w spiżarce „okno [...] małe deszczką zabite”34. W niektórych siedzibach w tego typu pomieszczeniach okna nie miały szyb a zamykano je okiennicami ${ }^{35}$. Niekiedy źródła informowały o istnieniu wewnętrznych okien w kuchni, służących do wydawania potraw ${ }^{36}$.

Powszechnie również notowano stan otworów okiennych w poszczególnych pomieszczeniach. Wielokrotnie wspominano zarówno o dobrym — „okien pięć dobrych, w ołów oprawnych” (Solec, pow. opoczyński, 1670), jak i znacznie częściej o złym ich stanie — „okna we wszystkim budynku potłuczone, nie restaury, ale nowiny potrzebujące” (Trzemoszna, pow. opoczyński, 1688), „okien 4 szklane w ołów robione do górnych pokojów, bez zawias, częścią potłuczone, kwater do okien bez szkła 13" (Zgłobień Stary, pow. pilzneński, 1721) ${ }^{37}$.

Analizowane dokumenty nie zawierają natomiast tylu zróżnicowanych informacji na temat drzwi, zarówno wejściowych, jak i wewnętrznych ${ }^{38}$. W wielu przypadkach (co po części wynika też z lakoniczności opisów) w ogóle brak danych o drzwiach prowadzących do sieni wprost z podwórza lub z ganku ${ }^{39}$. W większości siedzib wymieniono drzwi wejściowe, ale nie podawano szczegółów o ich konstrukcji, np.: ,wchodząc do sieni drzwi na zawiasach żelaznych, [...] kołowrotkiem się zawierają” (Oblęgor Większy, pow. chęciński, 1722) lub „drzwi u sieni na biegunie i wici dębowej, z klamką drewnianą" (Skoszyn, pow. sandomierski, 1741) ${ }^{40}$. Zapewne chodzi tu o drzwi prostej, „,iesielskiej roboty”. Chociaż niekiedy nawet takim zwykłym drzwiom poświęcano nieco więcej uwagi, jak np. w Nawodzicach (pow. sandomierski, 1690), gdzie stwierdzono „drzwi proste, drewnianymi gwoździami zbite, na biegunach drewnianych, z wrzeciądzem i skoblem, zasuwa drewniana"41, albo we wsi Jałowęsy (pow. sandomierski, 1735), gdzie drzwi do sieni: ,z tarcic sosnowych z szpągami na zawiasach i hakach żelaznych, u tych drzwi klamka, zasuwa drewniana"42. Nieczęsto natomiast wspominano o drzwiach wykonanych „stolarską robotą"43. Do wyjątków zaś należą relacje o solidnych skrzydłach wejściowych, np. zamocowanych w Zgłobieniu Starym (pow. pilzneński, 1721): „drzwi wielkie dębowe na 3 zawiasach żelaznych, z zamkiem stolarskim dobrym wnętrznym, z antabami 2 i z klamką”, oraz w Otfinowie (pow. wiślicki, 1739): „drzwi wielkie stoczyste na zawiasach, hakach, z gałką, wrzeciądzem, haczykiem i z skoblami żelaznemi". Sporadycznie także wzmiankowano, że były one malowane, jak np. w przejściu z ganku do sieni w drewnianych oficynach w Skórkowicach (pow. opoczyński, 1748) ${ }^{44}$.

32 Źródła. 2013, s. 35, 80, 97.

33 Tamże, s. 40, 106.

${ }^{34}$ Tamże, s. $183-184$.

${ }^{35}$ M.in.: ANKr., ASangR., sygn. 375, nlb (,okno w ścienie bez szyb, okiennica z deszczek zasuwana”).

${ }^{36}$ Źródła. 2013, s. 61, 115.

37 Tamże, s. 71, 95; Źródła. 2016, s. 78.

${ }^{38}$ Por. Krótka nauka. 1957, s. 25; Łoziński W. 1958, s. 83.

${ }^{39}$ M.in. Źródła. 2013, s. 71; Źródła. 2016, s. 21.

${ }^{40}$ Źródła. 2013, s. 149; Inwentarz. 2001, s. 171-172; por. Źródła. 2016, s. 147 („Z tego ganku drzwi do sieni na zawiasach żelaznych", Żuków, pow. radomski, 1742).

${ }^{41}$ M.in. Źródła. 2013, s. 105.

${ }^{42}$ ANKr., ASangR., sygn. 365 , s. 2.

${ }^{43}$ M.in.: Źródła. 2013, s. 188; Źródła. 2016, s. 125.

${ }^{44}$ Źródła. 2016, s. 78, 132; Inwentarz. 2005a, s. 185. 
Wnętrza siedzib, zwłaszcza szlachty mniej zamożnej, z reguły zaopatrzone były w drzwi proste drewniane, zbite z tarcic, czasami „,stolarskiej roboty” ${ }^{45}$. Rzadko zaś wspominano o innych — dwuskrzydłowych ${ }^{46}$, zasuwanych, „składanych” oraz „forsztowanych alias podwójnych”47. Inwentaryzatorzy podawali czasem, $\mathrm{z}$ jakiego drewna zostały one wykonane; prócz dębiny w pojedynczych przypadkach zastosowano drzewo jodłowe i lipowe ${ }^{48}$. Drzwi określane jako żelazne, bardziej trwałe, umieszczano jedynie w wejściach do skarbców, np. w murowanej kamienicy w Skórkowicach (pow. opoczyński, 1748) i we dworze we wsi Zgłobień Stary (pow. pilzneński, 1721). Posiadały one żelazne wrzeciądze, skoble, zamki i kłódki ${ }^{49}$.

Nieczęsto w analizowanych źródłach zamieszczano dokładniejszy opis drzwi wewnętrznych; $\mathrm{z}$ takim mamy do czynienia m.in. w przypadku drewnianego, lecz obszernego dworu Sanguszków w Grocholicach (pow. sandomierski, 1720): „drzwi z tarcic całe oblistwowane, na 2 zawiasach wielkich i hakach żelaznych, z klamką, ab extra półklamczem, wrzeciądzem we 3 ogniwa i 2 skoblami żelaznymi, ab intra haczykiem i 2 skoblami żelaznymi" 50 .

Przeważnie skrzydła drzwiowe mocowane były na metalowych zawiasach, z kolei w siedzibach drobniejszej i średniej szlachty na „drewnianych biegunach" ${ }^{51}$. Zaopatrzone były w rozmaite elementy służące do ich wzmocnienia i umożliwiające zamykanie, których budowę w tym miejscu pominę: skoble, wrzeciądze, haki, klamki, gałki, antaby, zapadki, kołki, kołowrotki, zasuwki oraz zamki (w tym wymieniano: wewnętrzne, ślepe, „gdańskie”, ,ingrychtowe o dwu folach", z kluczami, itp.).

Do niezbędnych elementów wyposażenia siedzib szlacheckich należały urządzenia ogniowe w postaci pieców (grzewczych i piekarniczych) i kominków (oraz trzonów kuchennych) ${ }^{52}$.

Piece ogrzewały z reguły wszystkie wnętrza mieszkalne we dworze. $Z$ opisów wynika, że niejednokrotnie jeden piec służył do podniesienia temperatury w dwóch takich pomieszczeniach, jak np. we dworze w Otfinowie (pow. wiślicki, 1739), w którym — jak zapisano — „piec obadwa pokoje grzeje, kafle białe lazurowe, mało co całych" ${ }^{53}$. Piece budowano przy użyciu kafli „polewanych” (czyli o powierzchni pokrytej szkliwem), niekiedy wznoszono je częściowo z gliny i częściowo z kafli ${ }^{54}$. Zdecydowana większość kafli z pieców stojących w pomieszczeniach ,pańskich” była koloru zielonego ${ }^{55}$, a ponad dwukrotnie mniej było białych ${ }^{56}$, przy czym nie zaobserwowałem tu wyraźnych związków z chronologią funkcjonowania siedzib. W większości przypadków barwa kafli użytych do zestawienia kilku grzejników w obrębie jednej siedziby była taka sama. Nie zawsze jednak tak było, m.in. w Trzebiatowie (pow. opoczyński, 1745) w jednej z izb stał piec z białych, w izdebce zaś z kafli zielonych, we dworze w Woli Żelechowskiej (pow. stężycki, 1729) w izbie głównej piec zielony, w drugiej izbie — zbudo-

45 Źródła. 2013, s. 71; ANKr., CCR, t. 126, s. 363-381; Źródła. 2016, s. 125-126.

${ }^{46}$ Źródła. 2013, s. 71, 183-184; Źródła. 2016, s. 78-80; Inwentarze. 1999, s. 154.

47 Źródła. 2016, s. 29-30, 78-80, 182-183.

48 Źródła. 2013, s. 131-135; Źródła. 2016, s. 21, 78-80; ANKr., AKP, sygn. 2340, k. 1 (drzwi lipowe do skarbca w starym dworze w Łubnicach, pow. sandomierski, 1705); B. Oss., rkps 11613/III, s. 167.

${ }^{49}$ Inwentarz. 2005a, s. 185-186; Źródła. 2016, s. 78; por. Pielas J. 2018, s. 129-130.

${ }^{50}$ Źródła. 2016, s. 52.

${ }^{51}$ M.in. Źródła. 2013, s. 40-43, 91.

${ }^{52}$ Krótka nauka. 1957, s. 26-27. Na temat urządzeń ogniowych w dworkach szlacheckich, zob. szeroko Rozbicka M. 1999, s. 159-175, 225-232.

${ }^{53}$ Źródła. 2016, s. 132.

${ }^{54}$ M.in.: Inwentarz. 1996, s. 181-196; Źródła. 2016, s. 21, 78-80, 148 (Żuków, pow. radomski, 1742: „piec w glinę murowany do połowy, dalej w kafle ku wierzchowi robiony").

${ }_{55}$ M.in.: AGAD, ARzN, sygn. 836, s. 4; Źródła. 2013, s. 40-43; Źródła. 2016, s. 21; Inwentarze. 1999, s. 155; Inwentarz. 2001, s. 172. Na temat kafli piecowych, zob. m.in. Dąbrowska M. 1987.

${ }^{56}$ M.in.: Inwentarze. 1999, s. 155; Źródła. 2013, s. 35; Źródła. 2016, s. 116, 132 (Otfinów, pow. wiślicki, 1739: ,kafle białe lazurowane”). 
wany z kafli białych ${ }^{57}$. Kilkakrotnie odnotowano użycie kafli o odmiennej kolorystyce: żółto-zielonej w izbie stołowej w Szczekarzowicach (pow. opoczyński, 1666) i brunatnej z białymi kwiatami w takiejż izbie w Nawodzicach (pow. sandomierski, 1690). Natomiast w gabinecie narożnym pałacu w Żelechowie (pow. stężycki, 1729) znajdował się ,piecyk z kaflów gdańskich z modra biało polewanych" 58 . Piec wzniesiony z kafli gdańskich, z ozdobnymi koronami i gałkami, opisano we dworze w Strzyżowie (pow. pilzneński, 1747) ${ }^{59}$. Inwentarz wspomnianego wyżej pałacu w Żelechowie jest jedynym, w którym wspomniano o innym niż gdańskie pochodzeniu kafli (z Kocka, miasteczka w województwie lubelskim), a także — zapewne z uwagi na ich oryginalność - o ornamentach heraldycznych zdobiących lico użytych kafli, w postaci herbów Stanisława Mateusza Rzewuskiego, hetmana wielkiego koronnego (1726-1728) ${ }^{60}$.

Poza standardowymi opisami pieców (takimi jak ,,piec biały dobry”61), w niektórych inwentarzach zamieszczono również nieco więcej wiadomości, pozwalających na wnioskowanie o ich konstrukcji lub aktualnym stanie zachowania (,piec zielony kaflowy na prętach żelaznych”, „piec stary niedobry, brunatny z białymi kwiatami, miejscami gliną polepiony”, ,piec kaflowy zielony zły, polepiony”, ,,piec zrujnowany, bo tylko znak jest, gdzie przedtym był”) oraz — niekiedy — o kształcie (,,piec okrągły zielony, zły”) ${ }^{62}$.

W piekarniach, izbach czeladnych i kuchniach ulokowanych wewnątrz siedzib szlacheckich znajdowały się piece przeznaczone do rozmaitych wypieków. Niejednokrotnie w izbach piekarnianych mieściły się dwa takie urządzenia, jak np. w Ciepielowie (pow. radomski, 1619), gdzie stwierdzono „dwa pieca piekarniane z cegły murowane, na których jest piec zielony [z] polewanych kaflów”, oraz w Stawowicach (pow. opoczyński, 1670), gdzie zanotowano „dwa pieca - czarny i biały”63. Jak się wydaje, piece „białe” służyły raczej do ogrzewania pomieszczenia. Poświadcza to chociażby wzmianka na temat piekarni dworku we wsi Nowe (pow. sandomierski, 1678), w której istniał ,piec kaflowy stary, drugi piekarski”. W takiej izbie w Bodzechowie (pow. sandomierski, 1622) znajdował się „piec czarny, przy niem kominek gliniany do świecenia ${ }^{64 ”,}$ a w Skoszynie (pow. sandomierski, 1741) funkcjonował ,piec piekarniany cegłą wymurowany. Przy tym piecu kominek w lepiankę do sieni wywiedziony" ${ }^{65}$. We dworze w Woli Żelechowskiej (pow. stężycki, 1729), w kuchence usytuowanej w sieni i wymurowanej z cegieł, umieszczono zarówno „piec czarny do pieczenia chleba”, jak i „komin z gliny lepiony, na dwór wywiedziony”. Stąd był także dostęp do urządzeń ogrzewających dom — „czeluści 2 do pieców izdebnych"66.

Blisko pieców służących jako grzejniki w pomieszczeniach mieszkalnych budowano kominki, równie istotne źródła ciepła i światła. W zależności od zamożności użytkowników lub konstrukcji siedziby były one zrobione $\mathrm{z}$ gliny ${ }^{67}$, z gliny na ceglanej podmurówce ${ }^{68}$ lub w całości

57 Źródła. 2013, s. 157; Źródła. 2016, s. 125.

58 Inwentarze. 2003, s. 137-138; Źródła. 2013, s. 106; Źródła. 2016, s. 101.

59 B. Oss., rkps 11613/III, s. 167 („piec kaflowy na fundamencie murowany [z] gdańskich białych kafli, o trzech skrzyniach, z koronami dwiema i czterema gałkami”).

60 Źródła. 2016, s. 99-102. O ornamentyce kafli w dworkach szlacheckich, zob. m.in.: Łoziński W. 1958, s. $83-84$.

${ }^{61}$ Inwentarze. 2003, s. 138; Źródła. 2013, s. 71.

62 Inwentarz. 2001, s. 172; Źródła. 2013, s. 57, 105-107.

${ }^{63}$ Inwentarz. 1996, s. 181-196; Źródła. 2013, s. 62. Piec czarny to zapewne urządzenie z otwartym paleniskiem, z którego dym rozchodził się po całym pomieszczeniu; natomiast piec biały — z paleniskiem obudowanym.

${ }^{64}$ Był to prawdopodobnie kominek lepiony z gliny, będący głównym źródłem światła we wnętrzu.

65 Źródła. 2013, s. 16, 89; Inwentarz. 2001, s. 172.

66 Źródła. 2016, s. 125.

${ }^{67} \mathrm{~Np}$. Barycz (pow. opoczyński, 1763) — „komin prosty z gliny duży”, Źródła. 2013, s. 184.

${ }^{6} \mathrm{~Np}$. Ujście (pow. sandomierski, 1663) — „komin do siennego wychodzi, który w sieni lepiony [...] od dołu cegłą", tamże, s. 29. 
murowane ${ }^{69}$. Wśród wzmianek na temat tych urządzeń cenne są te, które zawierają informacje o ich kształcie i sposobie budowy. I tak np. w izbie stołowej w Zgłobieniu Starym (pow. pilzneński, 1721) obok pieca funkcjonował ,komin kapiasty murowany”, w alkierzyku dworu w Nawodzicach (pow. sandomierski, 1690) „kominek szafiasty murowany”70. Spisujący inwentarze rejestrowali ponadto istnienie żelaznych blach w kominkach ${ }^{71}$. Kominy stojące w sieniach najczęściej miały prostszą konstrukcję — były gliniane, posadowione „na sztuczkach” lub „,na sochach”72.

W związku z tym, że część analizowanych siedzib to budynki piętrowe lub z poddaszem, w którym lokowano najczęściej pomieszczenia gospodarcze ${ }^{73}$, istotną rolę pełniły wewnętrzne schody ${ }^{74}$. Na kilkanaście przypadków, gdy wspominano o schodach wewnętrznych, wszystkie umieszczone były $\mathrm{w}$ sieni ${ }^{75}$. Wykonane były $\mathrm{z}$ drewna, zabezpieczone poręczami $\mathrm{z}$ balasów, dylów lub tarcic ${ }^{76}$. Nieco więcej uwagi — na tle pozostałych zapisów — poświęcił tym elementom autor inwentarza dworku we wsi Zgłobień Stary (pow. pilzneński, 1721), który zanotował, że były tam ,wschody wielkie drzewiane, stolarską robotą robione, z balasami po stronach toczonymi, ale po jednej stronie wybrane balasy są"77. We dworze w Strzyżowie (pow. pilzneński, 1747), jak podano w dokumencie, drewniane schody liczyły dziewięć stopni ${ }^{78}$. Czasem schody na górę zastępowała drabina ustawiona w sieni, m.in. w Ciechominie (pow. stężycki, 1729) i w Żukowie (pow. radomski, 1742) ${ }^{79}$.

Sporządzający inwentarze zwracali też uwagę na stan podłóg zwanych pawimentami oraz sufitów - pułapów, pował, zaznaczając przy tym materiał, z którego były one zrobione ${ }^{80}$. W pomieszczeniach mieszkalnych, przede wszystkim zaś w izbach stołowych (wielkich), przeważały podłogi drewniane, w tym z tarcic ${ }^{81}$ lub dylów ${ }^{82}$. We wnętrzu o takiej funkcji we dworze grocholickim (pow. sandomierski, 1720), gdzie pawiment zrobiony był z drewna, miejsce wokół pieca i komina wyłożono - zapewne ze względów bezpieczeństwa - kamiennymi płytami. W wielu analizowanych siedzibach szlacheckich izby miały posadzkę z płyt kamiennych ${ }^{83}$ lub ceglaną ${ }^{84}$. Kamień stosowano w tym celu również w mniej reprezentacyjnych wnętrzach, np. w izdebce dworku trzebiatowskiego (pow. opoczyński, 1745), na ganku w Zgłobieniu Starym (pow. pilzneński, 1721) oraz w skarbcu murowanej części siedziby w Skórkowicach (pow. opoczyński, 1748), w którym druga połowa podłogi wykonana została z dylów, tj. z drewnianych,

${ }^{69}$ M.in. ANKr., ASangR., sygn. 365, s. 3 („,kominek z cegieł mularską robotą”); Inwentarz. 2001, s. 172; Źródła. 2013, s. 47-48, 183-184; Inwentarze. 2003, s. 138; Źródła. 2016, s. 21.

70 AGAD, ARzN., sygn. 836, s. 4; Źródła. 2016, s. 78-80; Źródła. 2013, s. 106. Kominek kapiasty to taki, który stawiano w narożniku pomieszczenia, natomiast szafiasty usytuowany był w połowie długości ściany, Dąbrowska M. 1992, s. 178.

71 M.in. Źródła. 2013, s. 67-68, 71, 105-107, 157.

72 Zob. m.in. tamże, s. 42.

73 Por. m.in. Wyczański A. 1979, s. 347-355.

74 Zob. Krótka nauka. 1957, s. 25-26.

75 M.in.: AGAD, ARzN., sygn. 836, s. 4; Źródła. 2013, s. 40-43, 188; Źródła. 2016, s. 29; Pielas J. 2008, s. 72 (pow. opoczyński, Stużno, 1649).

${ }^{76}$ M.in.: Inwentarz. 1996, s. 181-196; Źródła. 2013, s. 2-3; Źródła. 2016, s. 52: „Na górę wschody drewniane, dylami ciosanymi dychtownie obite [...]”.

77 Źródła. 2016, s. 79.

78 B. Oss., rkps 11613/III, s. 167.

79 Źródła. 2016, s. 116, 148.

80 Por. Łoziński W. 1958, s. 83.

81 M.in. Źródła. 2013, s. 40-43, 61-62, 105-107; Źródła. 2016, s. 29-30; Inwentarze. 1999, s. 155.

82 Inwentarz. 2005a, s. 185; Źródła. 2013, s. 183-184; Źródła. 2016, s. 116, 125-126.

${ }^{83}$ M.in.: Źródła. 2013, s. 149-150; Inwentarz. 2005, s. 185; Źródła. 2016, nr 148 („W pokoju zaś posadzka kamienna [...]"), 154.

${ }^{84}$ Źródła. 2013, s. 2-3; Inwentarz. 1996, s. 188 (,pawiment w niej jest cegłą położony”). 
grubych desek ${ }^{85}$. W części lokalności, przede wszystkim o charakterze magazynowym, nie układano niekiedy żadnych podłóg ${ }^{86}$; powierzchnię stanowiło tu klepisko.

Sufity w izbach zrobione były z różnie obrabianego drewna ${ }^{87}$. Wyjątkowo wspomniano o detalu konstrukcyjnym — o istnieniu środkowej belki, zwanej siestrzanem, na której spoczywały belki poprzeczne. I tak, w Ciepielowie (pow. radomski, 1619) był „,połap cały we wszystkim o pięciu belkach i [z] sestramem” oraz „wirzch dobry o siedmiu belkach z sestramem” "88. W izbie stołowej dworku w Zgłobieniu Starym (pow. pilzneński, 1721) pułap wspierał się na dwóch filarach ${ }^{89}$. Niestety w opisach wystroju izb brak znanych skądinąd wzmianek o napisach wyrytych na siestrzanach, w swej treści zawierających zazwyczaj wezwanie do Boga o opiekę nad daną siedzibą ${ }^{90}$.

Stanowiące przedmiot analizy inwentarze tylko w kilku szlacheckich siedzibach $\mathrm{z}$ terenu Sandomierszczyzny wymieniają detale świadczące o dekorowaniu ścian we wnętrzach mieszkalnych. W drewnianych oficynach przy siedzibie w Skórkowicach (pow. opoczyński, 1748) malowany był pułap i ściany w izbie stołowej, pokoju pańskim i pokoiku oraz na ganku ${ }^{91}$. We dworku we wsi Wola Przecławowa (pow. opoczyński, 1661) wskazano „izbę stołową malowaną"92. Opisujący dwór w Grocholicach (pow. sandomierski, 1622) zaznaczył: „Malarska robota owego domu, malowanie wokoło okien, także i nade drzwiami siennemi”, w innym zaś miejscu sprecyzował, iż „w tej sieni nade drzwiami obojgiemi herby malowane" ${ }^{93}$. W pokoju w dworku w Szczucinie (pow. wiślicki, 1699) inwentaryzator zanotował powałę pobitą „płótnem malowanym, ale już złym"94. Prawdopodobnie ściany izb mieszkalnych były też bielone wapnem, chociaż nie ma na ten temat wiadomości w uwzględnionych przekazach. Praktyka ta była zapewne na tyle powszechna, że nie zapisywano tego w inwentarzach ${ }^{95}$. W żadnym $\mathrm{z}$ dokumentów nie zamieszczono natomiast informacji o nierzadkich w dworach szlacheckich tamtego okresu papierowych obiciach ścian, tzw. kołtrynach ${ }^{96}$. Mogły one być mocowane do listew, które jednak wzmiankowano na ścianach izb stołowych w Sandomierskiem, np. w dworku w Stawowicach (pow. opoczyński, 1670), gdzie „listwy dokoła ściany piękne”97.

Inaczej dekorowano rezydencje magnackie, np. nieistniejący od XIX w. pałac Ossolińskich w ich rodowym Ossolinie (pow. sandomierski, 1711). Inwentarze tej siedziby rejestrują, że w budynku tym istniały stropy ramowe oraz obrazy wzorowane na cyklu sześciu akwafort Stefano della Belli, przedstawiające wjazd do Rzymu kanclerza Jerzego Ossolińskiego w 1633 r. ${ }^{98}$

Obrazy były istotną ozdobą ścian omawianych dworków. Inwentarze dóbr ziemskich z terenu Sandomierszczyzny wymieniają je rzadko, obrazy traktowano bowiem z reguły jako mobilia, których nie pozostawiano kolejnemu użytkownikowi dworu. Najczęściej były to ob-

85 Źródła. 2013, s. 157; Źródła. 2016, s. 78; Inwentarz. 2005a, s. 185; por. także: B. Oss., rkps 11613/III, s. 167 (,posadzka z kamienia” w sieni i spiżarce dworu w Strzyżowie, pow. pilzneński, 1747).

${ }^{86}$ M.in.: ANKr., ASangR., sygn. 375, nlb; Źródła. 2013, s. 79-80.

${ }^{87}$ M.in.: Źródła. 2013, s. 183-184; Inwentarz. 2001, s. 172; Źródła. 2016, nr 52 (,powała nowa z drzewa ciosanego"), 78 (,pułap jugowany”), 90.

${ }^{88}$ Inwentarz. 1996, s. 189. Por. Źródła. 2013, s. 50 (Sady, pow. radomski, 1667).

89 Źródła. 2016, s. 78.

90 Łoziński W. 1958, s. 82; Bystroń J.S. 1976, s. 404.

91 Inwentarz. 2005a, s. 185.

92 Źródła. 2016, s. 13.

93 Źródła. 2013, s. 2-3.

94 ANKr., CCR, t. 126, s. 363-381.

95 Historia 1978b, s. 210; Łoziński W. 1958, s. 93-96.

96 Łoziński W. 1958, s. 84-85.

97 Źródła. 2013, s. 61-62, 65; por. tamże, s. 42.

98 Tamże, s. 131-135; por. Bania Z. 2000. 
razy religijne. W dworku szczucińskim (pow. wiślicki, 1699) znajdowały się dwa obrazy — Matki Boskiej Częstochowskiej i św. Barbary, w Stawowicach (pow. opoczyński, 1676) „obraz wielki NMP Częstochowskiej na płótnie”, zaś w Nowej Wsi (pow. sandomierski, 1690) „obraz NMP nade drzwiami w ramach" ${ }^{99}$. Z pewnością z malowidłami o świeckim charakterze, najpewniej portretami antenatów z rodu Duninów, właścicieli siedziby, mamy do czynienia we dworze we wsi Żuków (pow. radomski, 1742), gdzie w pokoju głównym wisiało „portretów alias obrazów do ściany przybitych $10 " 100$.

Jeśli chodzi o oświetlenie izb mieszkalnych, to poza wzmiankowanymi niejednokrotnie kominkami, pełniącymi funkcje grzewcze i zapewniającymi doświetlenie pomieszczen ${ }^{101}$, jedynie w dworku w Solcu (pow. opoczyński, 1670) izba stołowa wyposażona była w oryginalny „lichtarz u stragarza z rogami jeleniemi na łańcuchu żelaznym” ${ }^{102}$.

W omawianych siedzibach szlacheckich poza typowymi wnętrzami o przeznaczeniu mieszkalnym i gospodarczym z rzadka rejestrowano istnienie też innych, o specyficznej funkcji. Pomieszczeniom tym poświęcono już odrębne opracowanie ${ }^{103}$, dlatego $\mathrm{w}$ tym miejscu ograniczę się do syntetycznego przytoczenia najważniejszych ustaleń. Były to apteczki, o których informacji jest niewiele; zazwyczaj stwierdzano jedynie fakt ich istnienia i usytuowania w siedzibie ${ }^{104}$. Kilkakrotnie wymieniono, że zajmowane przez nie pomieszczenia miały okienka ${ }^{105}$, a sporadycznie informowano o ich ruchomym wyposażeniu. W sporych rozmiarów dworze we wsi Żuków (pow. radomski) w apteczce znajdowała się stara szafa (w 1742), później (w 1754) również półki ${ }^{106}$, natomiast w murowanej kamienicy w Skórkowicach (pow. opoczyński, 1748) szafy „na ustawienie szkła" ${ }^{107}$. W żadnym z powyższych inwentarzy nie wspomniano o jakichkolwiek medykamentach zgromadzonych w apteczkach lub wprost o naczyniach służących ich przechowywaniu ${ }^{108}$.

W kilku przypadkach odnotowano w obrębie siedziby istnienie skarbca do składowania cenniejszych sprzętów i przedmiotów. Pomieszczenie to było zazwyczaj murowane i dobrze zabezpieczone dzięki żelaznym elementom zamocowanym w oknach oraz solidnym — żelaznym lub dębowym drzwiom ${ }^{109}$. W części skarbców stały szafki i szafy ${ }^{110}$, natomiast z najobszerniejszego opisu skarbca w siedzibie w Zgłobieniu Starym (pow. pilzneński, 1721) wynika, że prócz rzeczy zużytych, w tym starych lub zepsutych krzeseł, bądź dodatkowych — obrazów, parawanu, umieszczono tam także wielkie skrzynie i szafę $e^{111}$.

W siedmiu przypadkach inwentaryzatorzy wzmiankowali lub krótko opisali funkcjonującą w siedzibie kaplicę ${ }^{112}$. O jednej z nich — we dworze w Wiewiórce (pow. pilzneński, brak daty,

${ }_{99}$ ANKr., CCR, t. 126, s. 363-381; Źródła. 2013, s. 67, 106. Obraz nad drzwiami (nie wiadomo jednak o jakiej tematyce) stwierdzono również w jednym z ,pokojów pańskich” siedziby w Otfinowie (pow. wiślicki, 1739), Źródła. 2016, s. 132.

100 Źródła. 2016, s. 148

${ }_{101}$ M.in.: Źródła. 2013, s. 2-3; por. Historia. 1978a, s. 263-262; Łoziński W. 1958, s. 82.

102 Źródła. 2013, nr 71.

103 Pielas J. 2018

104 Zob. m.in.: Źródła. 2013, s. 48, 134; ANKr., APK., sygn. 2340, k. 2; Inwentarze. 1999.

105 M.in.: Źródła. 2016, s. 25-26; ANKr., APK., sygn. 2340, k. 2.

106 Źródła. 2016, s. 148, 153-154.

107 Inwentarz. 2005a, s. 186.

108 Por. Pielas J. 2018, s. 128-129.

109 Inwentarz. 2005a, s. 185; Źródła. 2016, s. 78; Źródła. 2013, s. 131. Wyjątek stanowią drzwi do skarbca w starym dworze w Łubnicach (pow. sandomierski, 1705), do którego prowadziły drzwi lipowe, najpewniej bez dodatkowego wzmocnienia, danych takich brak w dokumencie, ANKr., APK., sygn. 2340, k. 1.

${ }^{110}$ Inwentarz. 2005a, s. 185 (,szafek w murze 3”); ANKr., APK., sygn. 2340, k. 1 (,szafa stolarskiej roboty wielka").

111 Źródła. 2016, s. 78; por. szerzej Pielas J. 2018, s. 129-131.

112 ANKr., APK., sygn. 2340, k. 1v; AGAD, AZ, sygn. 2833, s. 129; Źródła. 2013, s. 47, 106, 134; Źródła. 2016, s. 166; Inwentarze. 2003, s. 138. 
pierwsza połowa XVII w.) wiadomo, że pomalowana była na szary kolor ${ }^{113}$. O elementach ich ruchomego wyposażenia wiadomości jest mało. I tak, w kaplicy dworku nawodzickiego (pow. sandomierski, 1690) znajdował się stolik do odprawiania nabożeństwa, dwa stołki, trzy obrazy, w tym Męki Pańskiej, drewniana pasyjka oraz cztery szklane ampułki ${ }^{114}$. W kaplicy w pałacu ossolińskim (pow. sandomierski, 1711) — jak wyraźnie zaznaczono — nie było ołtarza, a znajdował się tam jedynie mały, prosty krucyfiks ${ }^{115}$. Najdokładniejszy opis takiego wnętrza dotyczy Nieświna (pow. opoczyński, 1742), ponieważ jednak była to kaplica wolno stojąca, inwentarz ten został pominięty w niniejszym opracowaniu ${ }^{116}$.

Tylko w jednym przypadku — dworku magnackiego w mieście Opatowie (pow. sandomierski, 1618) odnotowano łaźnię. Znajdował się w niej m.in. piec z miedzianym kotłem, trzy wanny, cztery cebrzyki, jeden ceber i mały szaflik ${ }^{117}$.

Znacznie częściej natomiast $\mathrm{w}$ uwzględnionych inwentarzach wspominano o miejscach (komórkach) sekretnych, zwanych także prywetami (prewetami), czyli o wychodkach, usytuowanych z oczywistych względów w pewnym oddaleniu od głównych izb mieszkalnych. Spisujący ograniczali się do określenia stanu prowadzących do nich drzwi ${ }^{118}$.

Pod względem mebli, najwięcej było ich w głównej izbie we dworze, zwanej najczęściej stołową, świetlicą lub pokojem wielkim, znajdującej się z reguły we frontowym trakcie budynku $^{119}$. Na przykład w takiej sali we dworze w Sroczkowie (pow. wiślicki, 1700) znajdowało się: ,stołów dwa, jeden sosnowy biały, a drugi lipowy wielki [...], szafa zielono malowana z zamkami z haczykami i ze wszytkiem [...] porząnna, [...] ławy za stołem stolarską robotą robione”, zaś w Solcu (pow. opoczyński, 1670): „służba stolarski roboty, przy służbie schowania pięcioro. Koło służby krata drzewiana [...]. Stołów para, jeden wymykany, drugi prosty dobry, ławy stolarski roboty po dwie stronie, zydel z poręczem przekładany, zydlików para". W pokoju wielkim w starym dworze w Żukowie (pow. radomski, 1754) stały: ,[...] kredens staroświecki na słupkach, z kratą u góry, z praską na dole, drzwiczki dwoiste na zawiaskach, ławy 2 przy ścianach, [...] stół duży okrągły”, z kolei w izbie w skromnym dworku we wsi Nietulisko (pow. sandomierski, 1707): „ławy przy ścienie dwie, szafa w kilka przegród [...], przy piecu ławek dwie, stół dębowy z podnóżem sosnowym, drugi stół prosty przy ścienie $\mathrm{z}$ fors $[\mathrm{z}] \mathrm{tu}$ "120.

Jak świadczą analizowane zapisy, w tym powyższe cytaty, w tych reprezentacyjnych wnętrzach w szlacheckich siedzibach dominowały następujące meble — „statki drewniane” (,statki domowe") ${ }^{121}$ : szafy, kredensy (określane też mianem służby), stoły, ławy, krzesła i zydle ${ }^{122}$. Relacje te wskazują, że w większości były to sprzęty proste, wykonane zapewne przez miejscowych rzemieślników.

Wzmianki na temat szaf i kredensów z reguły są dość lakoniczne, np.: „szafa wielka stara”, „służba zielona”, „kredens zamykany, drzwiczki na zawiasach z skobelkami i haczykiem żela-

113 AGAD, AZ, sygn. 2833, s. 129.

114 Źródła. 2013, s. 106.

115 Tamże, s. 134.

116 Źródła. 2016, s. 166. Por. Pielas J. 2018, s. 132.

117 Inwentarz. 2005b, s. 158. Por. ostatnio Bis W. 2007, passim.

118 M.in. ANKr., CCR, t. 126, s. 363-381; Źródła. 2013, s. 61, 19; Źródła. 2016, s. 78-80; Inwentarz. 1996, s. 189. Por. Krótka nauka. 1957, s. 27.

119 O roli izby stołowej we dworach szlacheckich m. in. Krótka nauka. 1957, s. 13; Łoziński W. 1958, s. 69.

120 Źródła. 2013, s. 71, 121; Źródła. 2016, s. 154; ANKr., ASangR., sygn. 375, nlb.

121 Określenie stosowane np. przez J. Dumanowskiego (2006, s. 46-48).

${ }^{122} \mathrm{Na}$ temat mebli w okresie nowożytnym zob. m.in.: Gostwicka J. 1965; Pośpiech A. 1992, s. 77-121; Główka D. 2001, s. 95-114; Betlejewska Cz. 2001; w pracach tych omówienie poszczególnych rodzajów sprzętów oraz literatura przedmiotu. 
znemi"123. W kilku wszakże przypadkach ich opisy pod względem szczegółowości można porównywać do informacji zawartych w pośmiertnych inwentarzach ruchomości. I tak np. w izbie stołowej dworu stawowickiego (pow. opoczyński, 1670) znajdowała się ,s[z]afa wielka malowana, do której jest dwoje drzwiczek na zawiesach żelaznych, zamku u jednej nie masz a drugi jest. W tejże szafie służba albo kredens, wyżej jest c[z]woro schowania na szkło, do którego jest dwoje drzwiczek kracianych na zawieskach żelaznych; cztery ich z jednym zamec[z]kiem". W Zgłobieniu Starym (pow. pilzneński, 1721) umieszczona była „szafa z kratą malowana dobra, mająca w sobie szuflad cztery, jedna wielka a trzy małych z zamkami i antabami, drzwi na zawiasach bez zamku w tej szafie”; w ,pałacu” drewnianym we wsi Ryków (pow. radomski) w 1707 r. stał „kredens nowy, w którym na spodzie szafek 2, do których drzwiczki na zawiaskach żelaznych, trzecia kratka we środku także na zawiaskach żelaznych, zameczków nie masz, za tą kratką szuflad 2 z antabami żelaznemi, drugich 2 nie masz, na wierzchu zaś są kraty 2 na zawiasach żelaznych, z hamulczykiem i zamkiem do zamknięcia”, zaś w 1742 r. ,szafa alias kredens, stolarska robotą w kratkę robiony, który i u góry i u dołu ma zamknięcie dwoiste" ${ }^{24}$. Niejednokrotnie wzmiankowano szafy — albo „malowane”, zwykle w kolorze zielonym ${ }^{125}$, albo „zamczyste" i ,wielkie" 126 . W poddanych analizie źródłach nie stwierdzono natomiast, znanych skądinąd, szaf z ornamentami intarsjowanymi lub inkrustowanymi, a także słynnych szaf i generalnie mebli gdańskich. Tylko w jednym inwentarzu, przy opisie izby wielkiej we dworze we wsi Wola Gieraszowska (pow. sandomierski, 1664) wymienione zostały naczynia przechowywane wewnątrz jednej z dwóch szaf; było to siedem półmisków, misa, miednica i cztery talerze cynowe ${ }^{127}$.

Stoły i stoliki w izbach stołowych i innych pomieszczeniach mieszkalnych były — jak można sądzić — najczęściej niewyszukane, wykonane z drewna dębowego, sosnowego bądź lipowego ${ }^{128}$. W źródłach odnotowano takie sprzęty w różnych kształtach, wielkości i konstrukcji, np. kwadratowe, okrągłe, rozkładane ${ }^{129}$. W alkierzyku dworku w Oblęgorze Większym (pow. chęciński, 1722) znajdował się „stolik dębowy, w którym marmur czarny śrzodkiem” ${ }^{130}$, w pokoiku narożnym w Zgłobieniu Starym (pow. pilzneński, 1721) „stolik kwadratowy sosnowy z nogami, z szufladą"131, w jednym zaś z pokoi we dworze we wsi Ryków (pow. radomski, 1707) „stołów 4-2 okrągłe małe, trzeci szafiasty składany wielki, czwarty prosty długi”"132.

Mebli do siedzenia zwykle nie opisywano dokładnie. Rzadko podawano określenia dotyczące surowca, z jakiego zostały zrobione, sposobu ich budowy, rozmiarów oraz stanu zachowania, np.: „ława stolarska”, „ławki z deszczek proste”, „ławy 2 wielkie pod oknami przez całą izbę”, „,aw dwie z delów ciosanych, sosnowe, dobre”133 lub „zydel z poręczem przekładany”

Ten podstawowy zestaw sprzętów domowych uzupełniały wymieniane incydentalnie skrzynie i skrzynki ${ }^{135}$ oraz łóżka. Te ostatnie zarejestrowano trzykrotnie: w izbie stołowej dworku w Stawowicach (pow. opoczyński, 1676), w alkierzu dworu w Stobierni (pow. pilzneński,

123 Źródła. 2013, s. 157, 183-184; Źródła. 2016, s. 78-80.

124 Źródła. 2013, s. 61; Źródła. 2016, s. 29-30, 148.

${ }^{125}$ M.in. Źródła. 2013, s. 40-43, 47-48, 50, 121.

${ }^{126}$ M.in. Źródła. 2016, s. 17, 132.

127 Tamże, s. 17.

128 Źródła. 2013, s. 95, 121; Źródła. 2016, s. 78-80.

${ }^{129}$ M.in. Źródła. 2016, nr 18, 19a; Inwentarze. 2003, s. 137-138; Inwentarze. 1999.

130 Źródła. 2013, s. 150.

131 Źródła. 2016, s. 79.

132 Źródła. 2013, s. 71; Źródła. 2016, s. 30.

${ }^{133}$ M.in. AGAD, ARzN, sygn. 836, s. 4; tamże, ASangR., sygn. 365, s. 2; Źródła. 2013, s. 40-43, 71, 105-107; Źródła. 2016, s. 30.

134 Źródła. 2013, s. 71.

${ }^{135}$ Inwentarz. 1996, s. 190; Źródła. 2016, s. 17. 
1723) oraz w Woli Gieraszowskiej (pow. sandomierski, 1664), gdzie w odrębnym budynku w podwórzu, w komnacie przyległej do izby znajdowało się „łóżko tokarskiej roboty jedno"136. We dworze w Zgłobieniu Starym (pow. pilzneński, 1721), w izbie pełniącej funkcję schowka, opisano zgromadzone tam rzeczy, z pewnością niektóre już nieużywane, w tym: „krzesła obite z poręczami 2, a bez poręczy 3, [...], skrzynie wielkie z zamkami żelaznymi 2, trzecia bez zamku, wysoka szafa bez zamku"137.

$\mathrm{Na}$ wyposażenie dworków szlacheckich składały się także rozmaite przedmioty niezbędne dla należytego funkcjonowania gospodarstwa, przechowywane w pomieszczeniach pomocniczych. Wśród nich wiele było rozmaitych pojemników, m.in. beczki, safarnie, fasy, toki, przykadki, niecki, cebry lub notowane jednostkowo wieszadło na chleb ${ }^{138}$ oraz ,pniak do rąbania mięsa" 139 .

Na podstawie badanych inwentarzy dóbr ziemskich można zrekonstruować tylko częściowo nieruchome i ruchome elementy wnętrz w szlacheckim domostwie, akta te spisywano bowiem najczęściej w momencie zmiany własności dóbr — dziedzicznej i użytkowej ${ }^{140}$. Z chwilą opuszczania dworu, właściciel lub dotychczasowy posesor najcenniejsze mobilia, w tym: wartościowe meble, obicia, ozdobną broń i części wojskowego rynsztunku ${ }^{141}$, obrazy, kilimy, kobierce, nie mówiąc o szatach, zastawie stołowej czy klejnotach, przechowywanych w rozmaitych skrzyniach i szkatułach, zabierał ze sobą do kolejnej siedziby. Stąd o tych kosztownych detalach wystroju dworów dowiadujemy się z innych źródeł — testamentów i różnych spisów należących do szlachty ruchomości, w tym z inwentarzy pośmiertnych.

W procesie spadkobrania szlacheckiego testamenty spełniały, jak wiadomo, istotną rolę, przede wszystkim w odniesieniu do mobiliów, podstawowe bowiem dla majątku spadkobierców dobra nieruchome dzielone były poprzez akty divisionis bonorum terrestrium ${ }^{142}$. W testamentach szlachta dysponowała przede wszystkim gotówką oraz właśnie ruchomościami, przekazywanymi wybranym przez siebie sukcesorom. W związku z tym akty ostatniej woli zawierają $\mathrm{z}$ reguły szereg informacji na temat przedmiotów, będących na wyposażeniu siedziby testatora ${ }^{143}$. Dokonanie jednak pod tym kątem szerszej analizy szlacheckich testamentów z terenu województwa sandomierskiego wydaje się obecnie przedwczesne, dotychczas bowiem dysponujemy edycją jedynie kilkudziesięciu aktów ostatniej woli szlachty z tego terenu ${ }^{144}$, a kontynuowana kwerenda dostarcza kolejnych tego typu archiwaliów. W związku z tym posłużę się tylko kilkoma ciekawszymi przykładami.

Mikołaj Spytek Ligęza, kasztelan sandomierski, przekazał swoim spadkobiercom w testamencie z 4 sierpnia 1637 r. m.in.: ,przedniejszą moskowską czarę z rubinami, diamentami, szmaragdami, z szafirami, szczerozłotą, z perłami”, skrzynie, w tym włoską oraz „białą srebrną, pospolitą, podróżną” i „,blachową [...] z przywilejami i kwitami”, ponadto „rzędy, rynsztunki wszelakie wojenne, lamparty, zbroje", a także obicia i opony do przyozdobienia ścian ${ }^{145}$. Zofia z Noskowskich Gniewoszowa, starościna radomska, prócz przejętego po mężu rynsztunku wojskowego, rozdysponowała w akcie ostatniej woli z 12 czerwca 1680 r. m.in. obicie ada-

136 Źródła. 2016, s. 17.

137 Tamże, s. 78. Wymieniono tam również „obrazów wielkich z ramami 3 różnych świętych [...], parawan dobry w trzy sztuki kładziony, malowany, na zawiaskach żelaznych”.

138 Źródła. 2013, s. 107.

139 Inwentarz. 1996, s. 189.

140 Zob. m.in. Leskiewicz J. 1953, s. 363-378 oraz wstępy do: Inwentarze. 1956; Inwentarze. 1955-1959.

${ }^{141} \mathrm{~W}$ analizowanych inwentarzach dóbr ziemskich tylko raz wymieniono broń — „samopał na ścienie”, w dworku w Woli Gieraszowskiej (pow. sandomierski, 1664), Źródła. 2016, s. 17.

142 Zob. Pielas J. 2013, passim.

143 O zagadnieniu tym w odniesieniu do szlachty sandomierskiej zob. Katra S., Suchojad H. 2000, s. 449-457.

144 Cui contingit. 2005.

145 Tamże, s. 91-102. 
maszkowe i kobierzec dywański ${ }^{146}$. Imponujący zbiór broni i sprzętu wojskowego, z których z pewnością znaczna część stanowiła ozdobę pomieszczeń mieszkalnych, posiadał zmarły na przełomie 1681 i 1682 r. Paweł Ligęza. Znajdujemy tam m.in.: ,rządzik biały płaski w tabliczki, rządzik złocisty w pukle wielkie z koralami, kusz wilki srebrny, szabel trzy w srebro oprawnych, buzdygan szczyrosrebrny [...], sajdak, misiurkę, łubie i strzały, kulbakę w srebro oprawną, z płatem, z wojłokiem żółtym, cztery węzły na skórce srebrne mającym, kotły żołnierskie, namiot chocimski, siedzenie tureckie haftowane czerwone, drugie fiołkowe haftowane, rząd złocisty usarski w kratkę robiony, rząd złocisty z turkusami i z diamentami czeskimi i z różnymi innymi kamieniami, kulbakę wołoską z ciemnozieloną poduszką, drugą kulbakę także pod Bundorowem u ordy wziętą, z sztuczkami szczyrosrebrnymi złocistymi, na skórce czerwonej drutem srebrnym haftowaną, bandolety cztery, półkirysus, pancerz, karwasz, szyszak złocisty, dek i dera turecka, pościel sukienna karmazynowa, materac, wał i poduszka, i drugi materac musułbasowy, uzdeczkę z multańska w sygnety robioną"147. W testamencie Józefa Popiela, stolnika nowogrodzkiego, z 16 kwietnia $1771 \mathrm{r}$. wymieniono, poza bronią i sprzętem wojskowym, także obrazy i portrety, zapewne przodków, zdobiące ściany jego dworku w Zielonce ${ }^{148}$.

Znacznie bogatsze od testamentów, pod względem liczby i szczegółowości opisu mobiliów należących do wyposażenia dworków, są pośmiertne inwentarze ruchomości ${ }^{149}$. Jako że dla szlachty dawnego województwa sandomierskiego nie dysponujemy obecnie licznym materiałem źródłowym tego rodzaju (obecnie trwa kwerenda w celu przygotowania edycji źródłowej kilkudziesięciu rejestrów ruchomości szlachty sandomierskiej z XVII-XVIII w.) ${ }^{150}$, również poprzestanę na wybranych przykładach.

W spisanym w 1697 r. dokumencie zamożnego szlachcica, Jana Topora Hynka, łowczego nadwornego koronnego, właściciela m.in. wsi Wyszmontów z dworem (pow. sandomierski), wśród wielu przedmiotów wymieniono te, które niewątpliwie były na wyposażeniu wspomnianego budynku. Do Hynka należały rozmaite części uzbrojenia i oporządzenia jeździeckiego (,szabla we złoto oprawna, szabla w blachmal oprawna, rządzik złocisty, rządzik drugi złocisty [...] sajdak blachmalowy", [...] kulbaka w blachmal oprawna, siedzenie husarskie [...], pistoletów prostych krzosowych, z olstrami i pokrowcami para, kulbaka prosta polowa"), materace i kobierce (,materac karmazynowy złocisty z wałem i płotkiem takimże. Wał aksamitny błękitny, z kutasem jedwabnym ze złotem, kobiercy dywańskich dwa [...], dek czerwony z konia, kobiercy małych dziesięć, kobiercy białych para”), meble (,skrzynia [...], zwierciadło w czarnych ramach, skrzyń próżnych złych bez zamków siedm, krzesełek gdańskich dwanaście, krzesełek sukiennych błękitnych starych dwoje”), instrumenty muzyczne („pozytew i wiola”), książki („książek kilka”) oraz drobniejsze sprzęty i naczynia domowe (m.in. „miednica z nalewką”, „,kocioł piwny miedziany”, „,bań gorzałczanych miedzianych starych dwie”, ,alembik miedziany, w nim garcy cztery”, , lichtarzów srebrnych dwa”, „zegarek ścienny w tarczę żelazny”, „,kałamarzyk cynowy jeden”, „,miseczek farfurowych cztery”) ${ }^{151}$.

Rejestr rzeczy ruchomych Sebastiana Czapskiego, podstarościego i sędziego grodzkiego chęcińskiego, sporządzony w 1669 r., pozwala domniemywać, że na wyposażeniu jego siedziby były m.in.: „materac i płotek atłasowy, kołdra kitajkowa, wszystko zielone. Kobierców nowych sześć, starych cztery, kilim perski pstry nowy, tureckie dwa, siedzenie kozackie”, ,strzelba: pistoletów par dwie, bandoletów par dwie, rus[z]nic trzy, muszkietów dwa, ładownica aksamitna nowa

146 Tamże, s. 114-122.

147 Tamże, s. 138-142.

148 Tamże, s. 157-159.

149 Zob. przede wszystkim: Pośpiech A. 1992; Dumanowski J. 2006. Literaturę odnoszącą się do rejestrów ruchomości jako źródeł historycznych (do 2013 r.) zebrał Pielas J. 2013, s. 104-106.

${ }^{150}$ Por. Pielas J. 2015, s. 629-635.

151 APL, TKL, sygn. 1012, s. 835-846. 
[h] aftowana[...]”, „księgi różne: historie i prawne”, „moździerz wielki spiżowy, lichtarzów cynowych dwa”, następnie sześć różnych skrzyń i trzy szkatuły, w tym „szkatuła sadzona cudzoziemska, w której wszytkie są sprawy i dyspozycyje, genealogia, kwity”, puzdra itp. ${ }^{152}$

Aleksander Ossowski, komornik graniczny opoczyński, przed śmiercią w 1674 r. posiadał w swej siedzibie m.in.: broń (dwa pistolety, dwa bandolety i fuzję), trzy zegarki, w tym „zegarek stołowy bijący prosty, mosiężny”, a także dwa perskie kilimy, kobierzec i „dywan wielki” oraz książki, w tym dzieła rzymskich klasyków ${ }^{153}$.

Znacznej wartości sprzęty, w tym także znajdujące się we dworze w Szczekarzowicach (pow. sandomierski), na przełomie XVI i XVII w. były własnością zamożnej szlachcianki, Małgorzaty z Tarłów Oleśnickiej ${ }^{154}$.

Wyjeżdżająca w 1652 r. z dworu w tychże Szczekarzowicach Anna z Korycińskich Oleśnicka, kasztelanowa wiślicka, zabrała ze sobą do miejsca dłuższego pobytu, prócz znacznej liczby odzieży, klejnotów, srebra i rozmaitych naczyń, również szkatuły, skrzynie, elementy rynsztunku wojskowego męża (w tym rzędy końskie, koncerz, szablę blachmalową), wiele obić (w tym szpalery), kobierce, lichtarze, a nawet dwoje nożyczek „do świec”, kałamarz i ,stykadent srebrny" 155 .

Zaprezentowane przykłady przedmiotów, uwzględnianych w testamentach i inwentarzach pośmiertnych, pozwalają uzupełnić surowe z reguły w swej wymowie i często enigmatyczne opisy szlacheckich siedzib zawarte w inwentarzach dóbr ziemskich. Dopiero one ukazują siedzibę szlachecką w XVII-XVIII w. jako miejsce użytkowania szerokiego asortymentu mobiliów, nadających pomieszczeniom charakterystyczny wystrój i klimat. Dla szlachty sandomierskiej — co w znacznej mierze wynika z niedostatków badanych źródeł pisanych — rzadko możliwe jest dla konkretnej osoby, w określonym przedziale czasowym, odtworzenie wyglądu zamieszkiwanego przez nią domu ${ }^{156}$. Dla okresu do połowy XVIII w. dla województwa sandomierskiego nie odnaleziono archiwaliów porównywalnych z powstającymi dopiero na przełomie XVIII i XIX w. remanentami ruchomości w siedzibach szlacheckich lub dyspartymentami mobiliów, a więc dokładnymi ich spisami, które w określonym czasie znajdowały się w poszczególnych pomieszczeniach lub były rozdysponowywane przez właścicieli do innych budynków ${ }^{157}$.

Chciałbym na koniec wyrazić przekonanie, że wykorzystanie szerszego zasobu źródeł pisanych, przede wszystkim reprezentatywnej liczby inwentarzy pośmiertnych, umożliwi w przyszłości dokładniejsze odtworzenie wystroju i wyposażenia dworów szlachty sandomierskiej w stuleciach XVII-XVIII. W następnym etapie pozwoli to na porównanie tych ustaleń $\mathrm{z}$ badaniami odnoszącymi się do siedzib szlacheckich na innych terenach Rzeczypospolitej.

Adres Autora:

dr hab. Jacek Pielas

Uniwersytet Jana Kochanowskiego w Kielcach

ul. Świętokrzyska 15

25-406 Kielce

jpielas@ujk.edu.pl

ORCID: 0000-0002-7165-8905

${ }^{152}$ ANKr., CCR, t. 97A, s. 365-368.

153 APK, ZAzRdz., sygn. 12, s. 51-54.

154 Pielas J. 2004, s. 307-315.

155 Pielas J. 2017a, s. 177-194.

${ }^{156} \mathrm{~W}$ przygotowaniu znajduje się opracowanie poświęcone kilku siedzibom szlachty sandomierskiej z XVII-XVIII w. na podstawie zachowanych kompletnie, wymienionych źródeł.

${ }^{157}$ Rejestr. 2018, s. 319-334. 


\section{BIBLIOGRAFIA}

\section{Źródła archiwalne}

AGAD [Archiwum Główne Akt Dawnych w Warszawie]:

ARzN [Archiwum Radziwiłłów z Nieborowa. Akta majątkowe i gospodarcze], sygn. 836.

AZ [Archiwum Zamoyskich], sygn. 2833.

ANKr. [Archiwum Narodowe w Krakowie (oddział na Wawelu)]:

CCR [Castrensia Cracoviensia Relationes], t. 97A, t. 126.

AKP [Archiwum Krzeszowickie Potockich], sygn. 2340.

ASangR. [Archiwum Sanguszków. Rękopisy], sygn. 365, 375.

APK [Archiwum Państwowe w Kielcach], ZAzRdz. [Zbiór Akt z Rdzowa], sygn. 12.

APL [Archiwum Państwowe w Lublinie], TKL [Trybunał Koronny Lubelski], sygn. 1012.

B. Oss. [Biblioteka Zakładu Narodowego im. Ossolińskich we Wrocławiu], rkps 11613/III.

\section{Źródla i opracowania publikowane}

Augustyniak Urszula. 2001. Drewniane dwory Radziwiłtów birżańskich w pierwszej połowie XVII wieku — rezydencje czy siedziby?, [w:] Rezydencje w średniowieczu i czasach nowożytnych, red. E. Opaliński, T. Wiślicz, Warszawa, s. 102-124.

Badowska Iwona. 1968. Pałac Tarlów w Podzamczu Piekoszowskim, „Rocznik Muzeum Świętokrzyskiego", t. 5, s. 79-107.

Bania Zbigniew. 2000. Zamek w Ossolinie. Jego dzieje i funkcja, [w:] Przemiany architektury rezydencjonalnej w XV-XVIII w. na terenie dawnego województwa sandomierskiego. Wybrane przyklady. Materiaty z sesji naukowej - Kielce, 18 września 1999, red. J.L. Adamczyk, Kielce, s. $89-102$.

Betlejewska Czesława. 2001. Meble gdańskie od XVI do XIX wieku, Gdańsk.

Bis Magdalena. 2014. Okna w zamku tykocińskim na początku XVIII wieku. Realia a wskazówki budowlane, [w:] Rzeczy i ludzie. Kultura materialna w późnym średniowieczu i w okresie nowożytnym. Studia dedykowane Marii Dabrowskiej, red. M. Bis, W. Bis, Warszawa 2014, s. 375-400.

Bis Wojciech. 2007. Nowożytna taźnia dworska w Radziejowicach, „Kwartalnik Historii Kultury Materialnej", R. LV, nr 2, s. 141-159.

Brykowska Maria. 2000. Fortalicja w Sobkowie. Przemiany architektoniczno-przestrzenne w XVI-XVIII wieku, [w:] Przemiany architektury rezydencjonalnej w XV-XVIII w. na terenie dawnego województwa sandomierskiego. Wybrane przykłady. Materiały z sesji naukowej - Kielce, 18 września 1999, red. J.L. Adamczyk, Kielce, s. 67-88.

Bystroń Jan Stanisław. 1976. Dzieje obyczajów w dawnej Polsce. Wiek XVI-XVIII, t. 2, Warszawa.

Chrzanowski Tadeusz. 1988. Wędrówki po Sarmacji europejskiej, Kraków.

Chudzińska Barbara, Chudziński Krzysztof. 1998. Założenia dworskie w Czarncy — próba rekonstrukcji na podstawie inwentarzy majatkowych spisanych w latach siedemdziesiatych XVII w., „Włoszczowskie Zeszyty Historyczne”, nr 5, s. 5-13.

Cui contingit. 2005. Cui contingit nasci, restat mori. Wybór testamentów staropolskich z województwa sandomierskiego, oprac. M. Lubczyński, J. Pielas, H. Suchojad, Warszawa.

Dąbrowska Maria. 1987. Kafle i piece kaflowe w Polsce do końca XVIII wieku, Wrocław.

Dąbrowska Maria. 1992. Kominek - luksus czy konieczność?, [w:] Nędza i dostatek na ziemiach polskich od średniowiecza po wiek XX, red. J. Sztetyłł, Warszawa, s. 177-181.

Dumanowski Jarosław. 2006. Świat rzeczy szlachty wielkopolskiej w XVIII wieku, Torun.

Hadamik Czesław. 2005. Średniowieczne dwory obronne w powiecie włoszczowskim, Włoszczowa.

Główka Dariusz. 2001. Rzeczy gdańskie w ruchomościach duchowieństwa katolickiego Rzeczypospolitej w XVII-XVIII w., „Kwartalnik Historii Kultury Materialnej”, R. XLIX, nr 1-2, s. 95-114.

Gostwicka Janina. 1965. Dawne meble polskie, Warszawa.

Historia. 1978a. Historia kultury materialnej Polski w zarysie, t. 3: Od XVI do połowy XVII w., red. A. Keckowa, D. Molenda, Wrocław. 
Historia. 1978b. Historia kultury materialnej Polski w zarysie, t. 4: Od połowy XVII do końca XVIII w., red. Z. Kamieńska, B. Baranowski, Wrocław.

Inwentarz. 1996. Inwentarz dóbr ciepielowskich z 1619 roku, wyd. S. Adamczyk, Z. Guldon, [w:] Radom i region radomski w dobie szlacheckiej Rzeczypospolitej, t. 2, red. Z. Guldon, S. Zieliński, Radom, s. 181-196.

Inwentarz. 2001. Inwentarz wsi Skoszyn z 1741 roku, wyd. W. Kalwat, J. Pielas, [w:] Między Wista a Pilica. Studia i materiaty historyczne, t. 2, red. G. Miernik, Kielce, s. 169-177.

Inwentarz. 2005a. Inwentarz dóbr skórkowickich z 1748 roku, wyd. J. Pielas, [w:] Między Wista a Pilica. Studia i materiaty historyczne, t. 6, red. L. Michalska-Bracha, B. Wojciechowska, Kielce, s. 181-191.

Inwentarz. 2005b. Inwentarz Opatowa i Ostrowca z 1618 roku, wyd. R. Kubicki, [w:] Między Wista a Pilica. Studia i materiały historyczne, t. 6, L. Michalska-Bracha, B. Wojciechowska, Kielce, s. $153-179$.

Inwentarze. 1955-1959. Inwentarze dóbr szlacheckich powiatu kaliskiego, t. 1-2, wyd. W. Rusiński, Wrocław.

Inwentarze. 1956. Inwentarze dóbr ziemskich województwa krakowskiego 1576-1700. Wybór z ksiąg relacyj grodu krakowskiego, oprac. A. Kamiński, A. Kiełbicka, S. Pańków, Warszawa.

Inwentarze. 1999. Inwentarze majętności sarnowskiej i grodeckiej z lat 1690 i 1707, wyd. J. Muszyńska, [w:] Radom i region radomski $w$ dobie szlacheckiej Rzeczypospolitej, t. 5, red. Z. Guldon, S. Zieliński, Radom, s. 153-170.

Inwentarze. 2003. Inwentarze dóbr szczekarzowickich z lat 1666 i 1685, wyd. J. Pielas, [w:] Między Wista a Pilica. Studia i materiaty historyczne, t. 4, red. G. Miernik, Kielce, s. 135-144.

Jakimowicz Teresa. 1979. Dwór murowany w Polsce w wieku XVI (wieża - kamienica - kasztel), Warszawa-Poznań.

Kajzer Leszek. 1972. W sprawie genealogii wiejskiej siedziby obronnej w Polsce, „Kwartalnik Historii Kultury Materialnej”, R. XX, nr 3, s. 451-465.

Kajzer Leszek. 2000a. O kilku dworach późnorenesansowych z Sandomierszczyzny, [w:] Przemiany architektury rezydencjonalnej $w X V-X V I I I$ w. na terenie dawnego województwa sandomierskiego. Wybrane przykłady. Materiały z sesji naukowej - Kielce, 18 września 1999, red. J.L. Adamczyk, Kielce, s. 51-66.

Kajzer Leszek. 2000b. Zamek w Rembowie w województwie sandomierskim, [w:] Przemiany architektury rezydencjonalnej $w X V-X V I I I$ w. na terenie dawnego województwa sandomierskiego. Wybrane przyklady. Materiały z sesji naukowej-Kielce, 18 września 1999, red. J.L. Adamczyk, s. 37-49.

Kajzer Leszek. 2004. Zamki i dwory obronne w Polsce Centralnej, Warszawa.

Kajzer Leszek. 2005. Późnośredniowieczne zamki na terenie dawnego województwa sandomierskiego, Kielce.

Katra Sylwia, Suchojad Henryk. 2000. Wyposażenie siedzib duchownych i szlacheckich $w$ świetle testamentów z XVII-XVIII wieku na terenie województwa sandomierskiego, [w:] Dwór polski. Zjawisko historyczne i kulturowe, Warszawa, s. 449-457.

Kołodziejski Stanisław. 2000. Wstęp do studiów nad średniowiecznymi rezydencjami obronnymi możnowładztwa w województwie sandomierskim, [w:] Przemiany architektury rezydencjonalnej w XV-XVIII w. na terenie dawnego województwa sandomierskiego. Wybrane przykłady. Materiaty z sesji naukowej - Kielce, 18 września 1999, red. J.L. Adamczyk, s. 9-18.

Krassowski Witold. 1995. Dzieje budownictwa i architektury na ziemiach polskich, t. 4, Warszawa.

Krótka nauka. 1957. Krótka nauka budownicza dworów, pałaców, zamków podtug nieba i zwyczaju polskiego, oprac. A. Miłobędzki, Wrocław.

Leskiewicz Janina. 1953. Znaczenie inwentarzy dóbr ziemskich dla badań historii wsi w Polsce w XVIII w., „Kwartalnik Historyczny”, R. LX, nr 4, s. 363-378.

Leśniakowska Maria. 1996. „Polski dwór”. Wzorce architektoniczne - mit - symbol, Warszawa. 
Lewicki Jakub. 2000. Pałac w Podzamczu Piekoszowskim - próba odtworzenia i analizy XVII-wiecznej architektury budowli, [w:] Przemiany architektury rezydencjonalnej $w X V-X V I I I w$. na terenie dawnego województwa sandomierskiego. Wybrane przykłady. Materiały z sesji naukowej-Kielce, 18 września 1999, red. J.L. Adamczyk, Kielce, s. 117-144.

Lubczyński Mariusz. 2017. Zespót dworski w Seceminie w świetle inwentarzy z 1654 i 1739 roku, [w:] Sztuka w Świętokrzyskiem. Średniowiecze i czasy nowożytne, red. P. Rosiński, H. Suchojad, Kielce, s. 269-283.

Łoziński Władysław. 1958. Życie polskie w dawnych wiekach, Kraków.

Madetko Sabina, Migaszewska Barbara. 2010. Zapomniana siedziba Lanckorońskich w świetle inwentarza wsi Wąworków z 1763 roku, „Studia Kieleckie. Seria historyczna”, nr 6, s. 53-61.

Marciniak-Kajzer Anna. 2000. Sandomierskie rezydencje Tarnowskich w XIV-XVII wieku, [w:] Przemiany architektury rezydencjonalnej $w X V-X V I I I$ w. na terenie dawnego województwa sandomierskiego. Wybrane przykłady. Materiały z sesji naukowej - Kielce, 18 września 1999, red. J.L. Adamczyk, Kielce, s. 19-36.

Miłobędzki Adam. 1976. Pałac i zamek „renesansowy”, [w:] Renesans. Studia i ideologia. Materiaty Sympozjum Naukowego Komitetu Nauk o Sztuce PAN, red. T. Jaroszewski, Warszawa, s. 413-419.

Miłobędzki Adam. 1980. Architektura polska XVII wieku, Warszawa.

Miłobędzki Adam. 1982. Polskie rezydencje wieku XVII - typowe programy i rozwiazania, [w:] Architektura rezydencjonalna historycznej Matopolski. Materiały Stowarzyszenia Historyków Sztuki, Łańcut, s. 8-16.

Mossakowski Stanisław. 2002. Orbis Polonus. Krzyżtopór a Caprarola, [w:] tegoż, Orbis Polonus. Studia z historii sztuki XVII-XVIII wieku, Warszawa, s. 23-55.

Nierychlewska Anna. 2002. Budownictwo obronne powiatu radomskiego w okresie od XIII do XVIII wieku, Radom.

Pielas Jacek. 2001. Dwór w Szczekarzowicach w świetle inwentarza z 1666 r., [w:] Między Wista a Pilica. Studia i materiaty historyczne, t. 2, red. G. Miernik, Kielce, s. 161-168.

Pielas Jacek. 2004. Majątek ziemski i ruchomy zamożnej szlachcianki w końcu XVI wieku. Przyczynek do dziejów wygastej linii Tartów herbu Topór, [w:] Między Wisła a Pilica. Studia i materiaty historyczne, t. 5, red. U. Oettingen, Kielce, s. 307-315.

Pielas Jacek. 2007. Oleśniccy herbu Dębno w XVI-XVII wieku. Studium z dziejów zamożnej szlachty doby nowożytnej, Kielce.

Pielas Jacek. 2008. Zaluscy herbu Junosza w pierwszej połowie XVII wieku. Z badań nad dziejami szlachty powiatu opoczyńskiego, [w:] Szlachta i ziemianie między Wista a Pilica w XVI-XX wieku. Studia z dziejów społeczno-gospodarczych, red. J. Gapys, M. Nowak, J. Pielas, Kielce, s. $53-75$.

Pielas Jacek. 2010. Dworki szlachty powiatu opoczyńskiego w XVII-XVIII wieku w opisie inwentarzy dóbr ziemskich, [w:] Z życia codziennego szlachty i ziemiaństwa między Wista a Pilica. Studia, red. J. Gapys, M. Nowak, J. Pielas, Kielce, s. 33-52.

Pielas Jacek. 2013. Podziały majątkowe szlachty koronnej w XVII wieku, Kielce.

Pielas Jacek. 2015. Inwentarze pośmiertne ruchomości szlachty sandomierskiej z XVII-XVIII wieku - perspektywy i problemy metodologiczne przygotowywanej edycji źródłowej, „Kwartalnik Historii Kultury Materialnej”, R. LXIII, nr 4, s. 629-635.

Pielas Jacek. 2017a. Dawnej świetności rodów sukcesorka. Anna z Korycińskich Oleśnicka, kasztelanowa wiślicka (zm. 1663) - życie, sprawy majątkowe i testament zamożnej szlachcianki z XVII wieku, [w:] Sic erat in votis. Studia i szkice ofiarowane Profesorowi Zbigniewowi Anusikowi w sześćdziesiąta rocznicę urodzin. Rzeczpospolita w czasach nowożytnych, red. M. Karkocha, P. Robak, Łódź, s. 177-194.

Pielas Jacek. 2017b. Siedziby magnackie $i$ szlacheckie $w$ województwie sandomierskim w inwentarzowych opisach dóbr ziemskich z XVII-XVIII wieku. Poczatek prac nad katalogiem, [w:] Sztuka w Świętokrzyskiem. Średniowiecze i czasy nowożytne, red. P. Rosiński, H. Suchojad, Kielce, s. $257-267$. 
Pielas Jacek. 2018. Od codzienności do świętowania. Skarbiec, apteczka, kaplica, sala balowa, altanka w siedzibach szlachty sandomierskiej w świetle inwentarzy dóbr ziemskich z XVII i XVIII wieku, [w:] Dom. Codzienność i święto. Ceremonie i tradycje rodzinne. Studia historyczno-antropologiczne, red. B. Popiołek, A. Chłosta-Sikorska, M. Gadocha, Kraków, s. 126-134.

Pośpiech Andrzej. 1992. Pułapka oczywistości. Pośmiertne spisy ruchomości szlachty wielkopolskiej z XVII wieku, Warszawa.

Rejestr. 2018. Rejestr ruchomości pałacu w Rusinowie z 7 grudnia 1801 roku. Przyczynek źródłowy do badań nad dziejami dworu szlacheckiego w Małopolsce przełomu XVIII i XIX wieku, wyd. K. Szpunar, „Almanach Historyczny”, t. 20, s. 319-334.

Rozbicka Małgorzata. 1999. Siedziby średniej i drobnej szlachty na pótnocno-zachodnim Mazowszu $w$ drugiej połowie XVIII i pierwszej połowie XIX wieku, Warszawa.

Szyposz Jadwiga. 1981. Odzież szlachty w świetle inwentarzy ruchomości zawartych waktach grodzkich i ziemskich województwa krakowskiego z lat 1645-1670, „Kwartalnik Historii Kultury Materialnej”, R. XXIX, nr 3, s. 349-364.

Szyposz Jadwiga. 1986. Przemiany odzieży szlachty Małopolski zachodniej w XVII wieku, „Kwartalnik Historii Kultury Materialnej”, R. XXXIV, nr 3, s. 451-461.

Wyczański Andrzej. 1979. Uwagi na temat dworu szlacheckiego w Wielkopolsce w XVI stuleciu, „Kwartalnik Architektury i Urbanistyki”, t. 24, z. 4, s. 347-355.

Źródła. 2009. Źródła i materiały do dziejów szlachty województwa sandomierskiego w XVI-XVIII wieku, t. 1: Rejestry pospolitego ruszenia szlachty sandomierskiej z XVII wieku, wstęp i oprac. J. Pielas.

Źródła. 2013. Źródła i materiały do dziejów szlachty województwa sandomierskiego w XVI-XVIII wieku, t. 2: Inwentarze dóbr ziemskich z XVII-XVIII wieku (cz. 1), wstęp i oprac. J. Pielas, Kielce.

Źródła. 2014. Źródła i materiały do dziejów szlachty województwa sandomierskiego w XVI-XVIII wieku, t. 3: Akty podziałów dóbr ziemskich szlachty sandomierskiej z XVII wieku, wstęp i oprac. J. Pielas.

Źródła. 2016. Źródła i materiały do dziejów szlachty województwa sandomierskiego w XVI-XVIII wieku, t. 2: Inwentarze dóbr ziemskich z XVII-XVIII wieku (cz. 2), wstęp i oprac. K. Justyniarska-Chojak, J. Pielas, Kielce.

\section{THE FURNISHINGS AND INTERIOR DECORATION OF NOBILITY MANOR HOUSES IN THE VOIVODSHIP OF SANDOMIERZ IN THE 17TH AND THE 1ST HALF OF THE $18 \mathrm{TH}$ C.}

The article discusses issues connected with the interior decoration and furnishings of the manor houses of petty, medium and affluent nobility in the voivodship of Sandomierz in the $17^{\text {th }}$ and the first half of the $18^{\text {th }} \mathrm{c}$., on the basis of printed estate inventories from the $17^{\text {th }}$ and $18^{\text {th }} \mathrm{c}$. and some inventories from handwritten sources. The article points to typical solutions, also noting the most interesting, sometimes unique examples of details and furnishings, especially in living quarters. It characterizes basic architectural elements - windows, doors, staircases, heating appliances (stoves and fireplaces), as well as wall decorations, lighting and furniture.

Examples drawn from estate inventories are supplemented with data from last wills and inventories of movables. The article stresses how important such data are to present a fuller picture of the analyzed interiors in the period in question. 